\title{
Pryloysis of Coffee Husks for Biochar Production
}

\author{
Nicholas Kiggundu*, Julius Sittamukyoto \\ Department of Agricultural and Bio-Systems Engineering, Makerere University, Kampala, Uganda \\ Email: ${ }^{\star}$ kiggundu@caes.mak.ac.ug
}

How to cite this paper: Kiggundu, N. and Sittamukyoto, J. (2019) Pryloysis of Coffee Husks for Biochar Production. Journal of Environmental Protection, 10, 1553-1564. https://doi.org/10.4236/jep.2019.1012092

Received: September 9, 2019

Accepted: November 29, 2019

Published: December 2, 2019

Copyright $\odot 2019$ by author(s) and Scientific Research Publishing Inc. This work is licensed under the Creative Commons Attribution International License (CC BY 4.0).

http://creativecommons.org/licenses/by/4.0/ (c) (i) Open Access

\begin{abstract}
Effective utilization of coffee wastes has been a great challenge in Uganda despite their wider use to replenish soil organic matter. This study explored the possibility of producing biochar from coffee husks that could be used as a soil amendment for replenishing soil nutrients and also for enhancement of soil water holding capacity. Pyrolysis of coffee husks was done in a batch bio-reactor under slow pyrolysis conditions of temperatures $350^{\circ} \mathrm{C}-550^{\circ} \mathrm{C}$ and residence times $30-60 \mathrm{~min}$. For easy characterization, biochar was grinded, sieved through a $1 \mathrm{~mm}$ sieve and then analyzed using a computerized Thermo Graphic Analyzer with an inbuilt and integrated ELTRA 84 $\mathrm{GmbH}$ Precision Digital weighing scale. Proximate analysis (wet basis) of biochar gave a moisture content of $5.2 \%$, ash content of $14.7 \%$, volatile matter of $13.2 \%$ and fixed carbon of $66.9 \%$. Biochar was applied to soil at different rates $(0 \%, 5 \%, 10 \%$ and $20 \% \mathrm{w} / \mathrm{w})$ and its effect on water holding capacity was investigated. Results show that biochar amended soils had higher water holding capacity $(p \leq 0.05)$ compared to biochar free soils. The water holding capacity also increased with increase in biochar amendment with a $1.5 \%$ increase in soil water holding capacity for each $1 \%$ increase in biochar application rate. Biochar was also rich in soil nutrient elements with $0.96 \% \mathrm{~N}, 0.39 \%$ $\mathrm{P}$ and $1.97 \% \mathrm{~K}$; this increased the availability of soil nutrients for crop growth. The results suggest that biochar could be a better tool to improve soil conditions thus enhancing the sustainability of agriculture.
\end{abstract}

\section{Keywords}

Coffee Husks, Pryloysis, Biochar, Soil Organic Matter, Soil Nutrients

\section{Background}

The effects of climate change/variability are experiences worldwide including Uganda [1]. The study on global warming shows that rapid temperature in- 
creases have been noticed all over the world [2]. The global warming of the earth results from emission of greenhouse gases into the atmosphere during burning of biofuels and decomposition of organic matter. International efforts have been put in place to reduce the greenhouse gas emissions through the sequestration of Carbon in the environment [2].

Global warming can be reduced worldwide through carbon sequestration processes into the soils. Pyrolysis of biomass wastes to yield biochar is a potential method of achieving carbon sequestration [3]. The biochar is a carbon rich compound containing about $50 \%$ carbon which is applied to soils as a soil amendment and carbon sequestration is achieved. Hence biochar can be used as a tool to mitigate the current climatic change and achieve sustainable development in developing countries like Uganda.

Uganda is one of the countries in the world with the highest rates of soil nutrient depletion [4]. Furthermore, the Ugandan population is increasing at a very high rate (3.1\%) compared to the world's population growth rate of $1.2 \%$ [5]. The imbalance between population growth rate and food production calls for concern about food security in the near future. The loss of soil fertility has led to the low yields in the agricultural sector which is the backbone of the Ugandan economy [6]. Soil fertility replenishment through the use of inorganic fertilizers in Uganda is too low $(1.8 \mathrm{~kg} / \mathrm{ha})$ compared to $(2.6 \mathrm{~kg} / \mathrm{ha})$ world average [7]. Furthermore, the inorganic fertilizers are expensive to the local farmers in terms of monetary value. They also consist of substances like methane and nitrous oxide whose emission has greatly contributed to the presence of green houses in the environment [8].

Uganda still lags behind in the use of biochar despite having the potential to generate adequate biomass feedstock for biochar production. Coffee is one of Uganda's most important commercial agricultural commodities, contributing approximately $20 \%$ to Uganda's foreign revenue [9] with an average annual production of 320,000 tons of unprocessed coffee.

The process of converting biomass to biochar leads to sequestration of about $50 \%$ of the initial Carbon content compared to the low amounts retained after biomass decomposition about $10 \%$ after 10 years [2]. Biochar hence offers a significant measure for climate change mitigation and restores the lost soil nutrients [10].

\section{Materials and Methods}

\subsection{Biochar Preparation}

The study was carried out at Makerere University Agricultural Research Institute Kabanyolo (MUARIK). Coffee husks were collected from Agro-max coffee processing mill located $13 \mathrm{~km}$ north of Kampala city. For pre-treatment purposes coffee husks were sun dried to a constant weight to reduce moisture content to below $12 \%$. Coffee husk was fed into a batch reactor (Figure 1) and heated to temperatures $350^{\circ} \mathrm{C}, 450^{\circ} \mathrm{C}$ and $550^{\circ} \mathrm{C}$ for residence times 30,45 and $60 \mathrm{~min}$ in a 


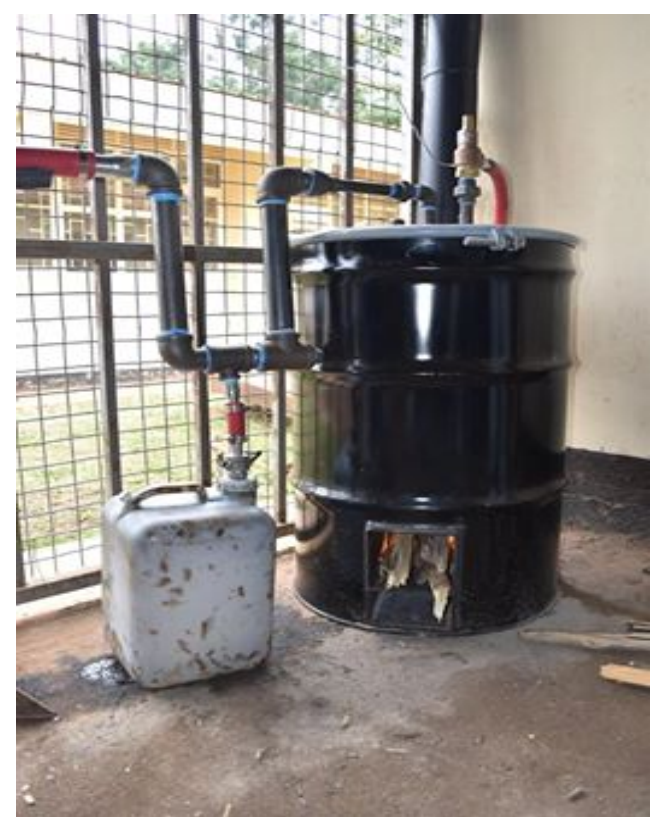

Figure 1. Pyrolysis of coffee husks in a batch reactor.

slow pyrolysis anaerobic setting as recommended by [11]. The pyrolysis process was carried out in a rector that was designed and fabricated by University of Kentucky Appropriate Technology and Sustainability (UKATS) research team. This rector was conceived using an appropriate technology (AT) concept and built in materials that are locally available in developing countries. The rector was used successfully in studies reported by ([12] [13] [14] [15]).

\subsection{Chemical Properties of Biochar}

The chemical properties included plant nutrient analysis (Nitrogen, Phosphorus and Potassium) and proximate analysis. The proximate analysis of the biochar was done using computerized T.G.A equipment with an inbuilt and integrated ELTRA $84 \mathrm{GmbH}$ Precision Digital weighing scale (Figure 2). The analyzer was integrated with a non oxidizing (99.99\% pure nitrogen gas) environment and an oxidizing (99.99\% pure oxygen gas) environment which are computer controlled by the T.G.A software version: TGA 1.4.2.12 with an internally programmed application for analyzing biochar properties in four stages namely; Moisture content, Volatile matter, Ash content and Fixed carbon. Volatile matter was determined as per [16] standard procedures.

\subsection{Plant Nutrient Analysis}

The nutrient analysis was conducted in the Soil science laboratory at the College of Agricultural and Environmental Sciences, Makerere University. This was to quantify the nutrients that were present in coffee husks biochar in terms of Nitrogen $(\mathrm{N})$, Phosphorus $(\mathrm{P})$ and Potassium $(\mathrm{K})$ which makes it a good soil amendment. Biochar was first converted to a plant tissue digest for easy analysis 


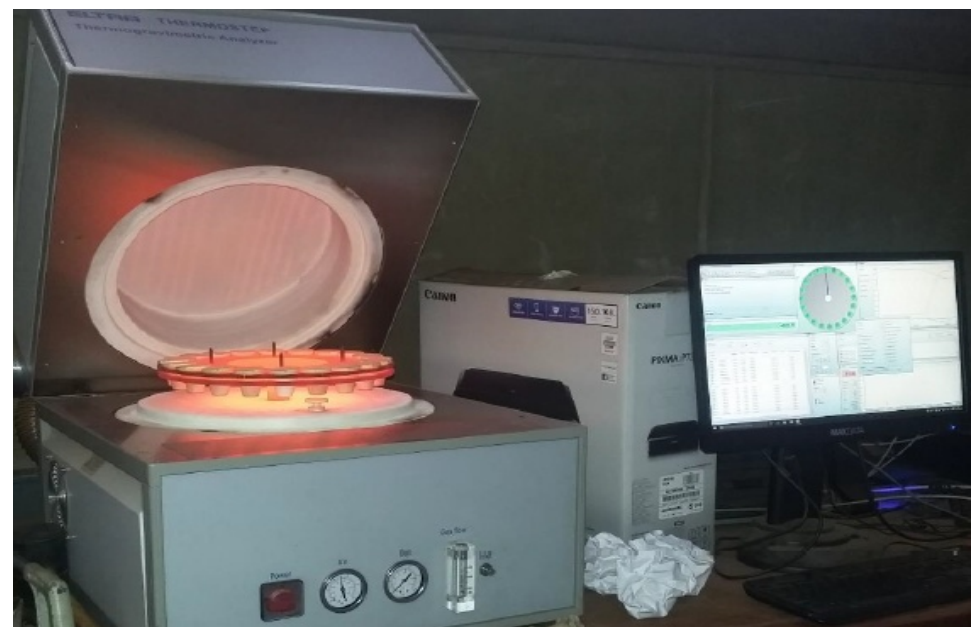

Figure 2. Computerized thermal graphic analyzer equipment with a precision digital weighing scale.

using the block digester procedure [17]. About $5 \mathrm{~g}$ of oven dried biochar sample was mixed with $2 \mathrm{ml}$ of digestive mixture in the digestion tube and heated at temperature of $110^{\circ} \mathrm{C}$ for about one hour. The solution was cooled and then successive drops of hydrogen peroxide were added until a colorless solution was attained. The solution was diluted with distilled water until no more sediment dissolved and a clear solution taken from the top of the test tube for analysis to determine the total Phosphorus, Potassium and Nitrogen in biochar.

\subsubsection{Analysis of Phosphorus}

The phosphorus content was determined without $\mathrm{pH}$ adjustment using Ascorbic acid. About $5 \mathrm{ml}$ of the digest solution was mixed with $10 \mathrm{ml}$ of ascorbic acid reducing agent, diluted with water, shaken well and then left to stand for about one hour to permit full color development. Using the colorimeter the sample absorbance (blue colour) at $880 \mathrm{~nm}$ wavelengths setting was measured and compared to the standard absorbance. The sample solution concentration and the blank solution concentration were determined from a standard graph of absorbance against concentration. The corrected concentration was obtained from subtracting the blank solution concentration value from the sample solution value. The Phosphorus content in the biochar sample was obtained in Equation (1)

$$
P(\%)=\frac{c \times 0.05}{w}
$$

where $c$, is the corrected concentration and $w$, is the weight of the dried sample.

\subsubsection{Analysis of Potassium}

The potassium content was determined by the Kjeldhal method followed by spectrometric analysis. About $2 \mathrm{ml}$ of the digested sample solution was diluted with $50 \mathrm{ml}$ of distilled water and mixed properly. The solution was sprayed into the flame of the flame photometer starting with standard, the sample and the 
blank solution. The amount of potassium concentration present in the solution was read off from the calibration curve prepared by plotting absorbance readings against potassium concentrations in standard series. The concentration of potassium in the biochar sample was calculated in Equation (2).

$$
K(\%)=\frac{(a-b) \times v \times f \times 100}{1000 \times w \times 1000}
$$

where $a$ is the concentration of potassium in the digest, $b$ is the concentration of the blank digest, $w$ is the weight of the sample, $v$ is the volume of the digest solution and $f$ is the dilution factor.

\subsubsection{Analysis of Nitrogen}

The nitrogen content was determined using the colorimetric method. The digest solution was diluted with distilled water and about $5 \mathrm{ml}$ of sodium citrate was added and then the mixture allowed stand for 2 hours. Using the colorimeter the sample absorbency at $650 \mathrm{~nm}$ was taken. A calibration curve was plotted and the concentration of Nitrogen in the solution read off.

The Nitrogen concentration in the biochar sample expressed in $\% N$ was calculated in Equation (3).

$$
N(\%)=\frac{(a-b) \times v \times 100}{1000 \times w \times a l \times 1000}
$$

where $a$ is the concentration of Nitrogen in the solution, $b$ is the concentration of Nitrogen in the blank, $v$ is the total volume at the end of the analysis procedure, $w$ is the weight of the dried sample and al is the aliquot of the solution.

\subsection{Experimental Design}

The experiment was carried out at Makerere University Agricultural Research Institute Kabanyolo (MUARIK) in plastic drained vessels. Biochar was applied to soil at different rates $(0 \%, 5 \%, 10 \%$ and $20 \% \mathrm{w} / \mathrm{w})$ with uniform soil mixing and all samples were packed to similar bulk densities depending primarily on the biochar application rate. Each treatment was replicated three times and each replicate included four different biochar application rates in a completely randomized design (Figure 3). All vessels were irrigated with similar volumes of

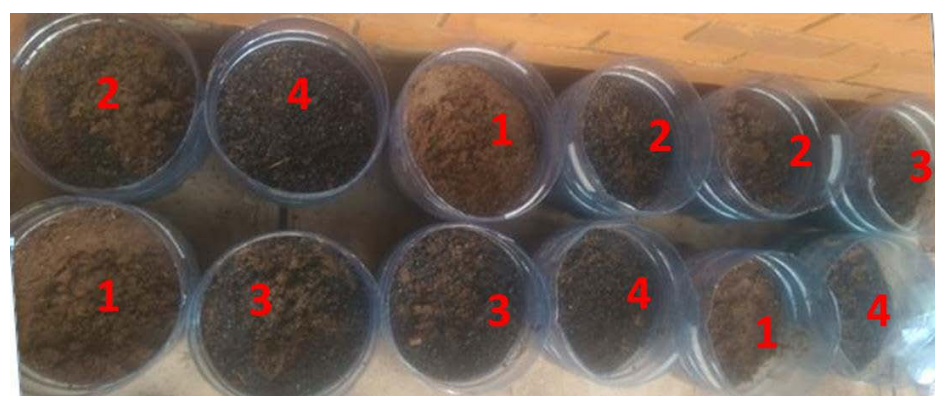

Figure 3. Soil samples with different treatments and their replicates (Where; $1=$ Control $-0 \%$ Biochar, $2=5 \%$ Biochar, $3=10 \%$ Biochar, and $4=20 \%$ Biochar). 
water until saturation and left in the shaded environment to prevent disruption from rain.

\subsection{Water Holding Capacity Analysis}

Soil samples were taken from each treatment at day 2 of the experiment and weighed in a pre-weighed container $\left(W_{1}\right)$. The total weight of moist sample and container $\left(W_{2}\right)$ were also taken. The samples were then dried in an oven at $105^{\circ} \mathrm{C}$ for two days until no further moisture loss occurred, reweighed and weight of oven-dried sample $\left(W_{3}\right)$ taken. The procedure was repeated for five corresponding days with varying moisture potentials and the water holding capacities of the soil were determined using Equation (4).

$$
W H C=\frac{W_{2}-W_{3}}{W_{3}-W_{1}} \times 100
$$

\subsection{Data Analysis}

The water holding capacities of soil resulting from different biochar application rates obtained from a Completely Randomized Design (CRD) experiment with three replications and four treatments were analyzed using the analysis of variance (ANOVA) to test the significance of the experiment among treatment means.

\section{Results and Discussions}

\subsection{Effect of Pyrolysis Conditions on Biochar Yield}

Temperature was one of the most important factors that affect the process of biomass pyrolysis. Biochar yield from coffee husks decreased when the pyrolysis temperature increased, with minimum yield of $29.9 \%$ recorded at $550^{\circ} \mathrm{C}$ and maximum yield of $35.09 \%$ recorded at $350^{\circ} \mathrm{C}$ (Figure 4). This was due to greater primary decomposition of the biomass samples or through the secondary decomposition of the biochar itself [18], since more volatile materials were being forced out of the char at higher temperatures reducing yield but increasing the proportion of carbon in the char as the pyrolysis temperature increased.

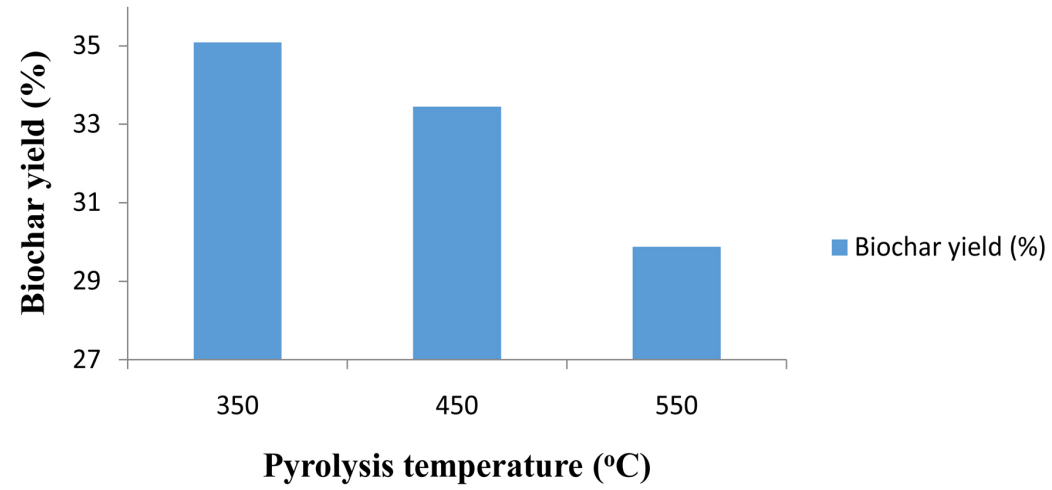

Figure 4. Variation of biochar yield with pyrolysis temperature. 
A decrease in the yield of the biochar was recorded with the increase in the pyrolysis residence time, with biochar maximum yield of $36.87 \%$ recorded in 30 min and minimum yield of $34.07 \%$ recorded in $60 \mathrm{~min}$ at a constant temperature (Figure 5). The time of heating of biomass affects the extent and sequence of pyrolytic reactions. Since pyrolysis takes place over wide range of time, products formed earlier tend to undergo secondary reactions and allow further degradation of the already formed products [18].

\subsection{Characterization of the Coffee Husks Biochar}

\subsubsection{Proximate Analysis of Coffee Husks Biochar}

Results for different biochar samples obtained from the computerized Thermo Graphic Analyzer (T.G.A) were recorded in Table 1 using the T.G.A software version.

The proximate analysis of the coffee husks biochar results in Table 1 shows that fixed carbon content in the biochar was above $60 \%$ for the pyrolytic conditions in all the tested samples implying that coffee husks biochar is suitable for carbon sequestration [19]. This high carbon content in biochar presents a valuable climate mitigation tool as use of biochar as a soil amendment by offsetting

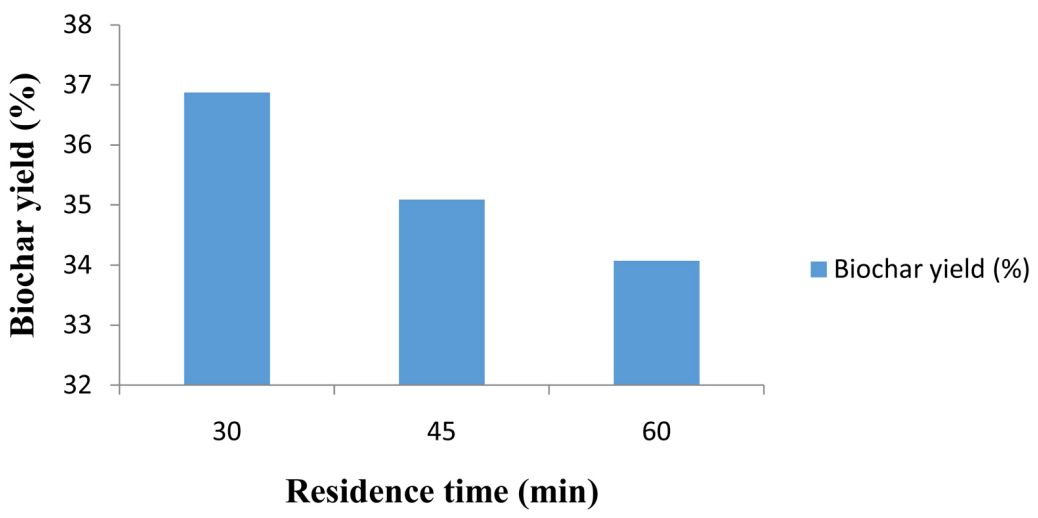

Figure 5. Variation of biochar yield with pyrolysis residence time.

Table 1. Results for proximate analysis composition of coffee husks biochar.

\begin{tabular}{ccccc}
\hline Biochar sample & $\begin{array}{c}\text { Fixed carbon } \\
(\%)\end{array}$ & $\begin{array}{c}\text { Ash content } \\
(\%)\end{array}$ & $\begin{array}{c}\text { Moisture } \\
\text { content }(\%)\end{array}$ & $\begin{array}{c}\text { Volatile matter } \\
(\%)\end{array}$ \\
\hline A-550-60 & 66.87 & 15.23 & 4.62 & 13.17 \\
A-550-45 & 65.43 & 14.48 & 4.96 & 14.98 \\
A-550-30 & 61.71 & 15.01 & 4.64 & 15.08 \\
B-450-60 & 64.01 & 14.64 & 5.49 & 19.62 \\
B-450-45 & 62.12 & 14.07 & 4.77 & 16.84 \\
B-450-30 & 63.73 & 12.92 & 5.93 & 17.12 \\
C-350-60 & 64.41 & 13.16 & 5.86 & 20.43 \\
C-350-45 & 63.92 & 13.38 & 6.07 & 18.73 \\
C-350-30 & 59.23 & 10.23 & 5.98 & 22.52 \\
\hline
\end{tabular}


carbon emissions into the atmosphere. The carbon present in biochar is held in an aromatic form and is resistant to decomposition when added as a soil amendment [20].

The second major component of biochar was the ash which contains important plant nutrients like Potassium, Phosphorus, Calcium and Magnesium [21]. When biochar is applied to the soil, the minerals contained in the ash alleviate deficiencies and improve crop growth. Volatile matter in the biochar was found to be low $(11 \%$ to $15 \%)$ which is a good indicator that the biochar is a good soil amendment tool. High volatile matter contains a bio available carbon source that stimulates microbial activity and inhibits nitrogen availability, while low volatile matter does not appear to be readily available for microbial consumption [22].

\subsubsection{Nutrient Analysis of Coffee Husks Biochar}

The coffee husks biochar results showed presence of higher nutrient content (Table 2) in terms of (NPK) compared to the $0.92 \% \mathrm{~N}, 0.29 \% \mathrm{P}$ and $0.67 \% \mathrm{~K}$ reported by [23] for maize stover biochar (Figure 6).

Also these nutrients in biochar are relatively higher compared to $0.12 \% \mathrm{~N}$, $0.03 \% \mathrm{P}$, and $0.24 \% \mathrm{~K}$ present in Ugandan soils reported by [4]. Therefore biochar used as soil amendment increases the availability of nutrients for plant growth.

\subsection{Water Holding Capacity of the Soil}

Results for average water holding capacities of soil amended with different biochar application rates for soil samples taken on various days Table 3.

Biochar amended soils had a significantly higher water holding capacity $(\mathrm{P}<$ 0.02) relative to the control while same treatments of biochar did not show any significant difference in the water holding capacity. An increase in biochar application rate increased the water holding capacity of the soil significantly at $(\mathrm{P}<$ 0.05 ) (Figure 7). Biochar application rate from $0 \%-5 \%, 5 \%-10 \%$ and $10 \%-$

Table 2. Nutrient content present in the coffee husks biochar.

\begin{tabular}{cc}
\hline Element & Quantity (\% wet basis) \\
\hline Phosphorus (P) & $0.39 \pm 0.002$ \\
Potassium (K) & $1.97 \pm 0.015$ \\
Nitrogen (N) & $0.96 \pm 0.005$ \\
\hline
\end{tabular}

Table 3. Water holding capacities of the soil under different biochar application rates.

\begin{tabular}{cccccc}
\hline \multirow{2}{*}{ Biochar application rates } & \multicolumn{5}{c}{ Water holding capacities of soil } \\
\cline { 2 - 6 } & Day 1 & Day 2 & Day 3 & Day 4 & Day 5 \\
\hline 0\%-control & 31.87 & 28.20 & 22.05 & 22.22 & 20.82 \\
$5 \%$ & 35.37 & 35.36 & 33.68 & 32.52 & 34.22 \\
$10 \%$ & 42.97 & 41.02 & 38.67 & 38.43 & 40.75 \\
$20 \%$ & 50.92 & 49.62 & 49.65 & 47.35 & 48.87 \\
\hline
\end{tabular}




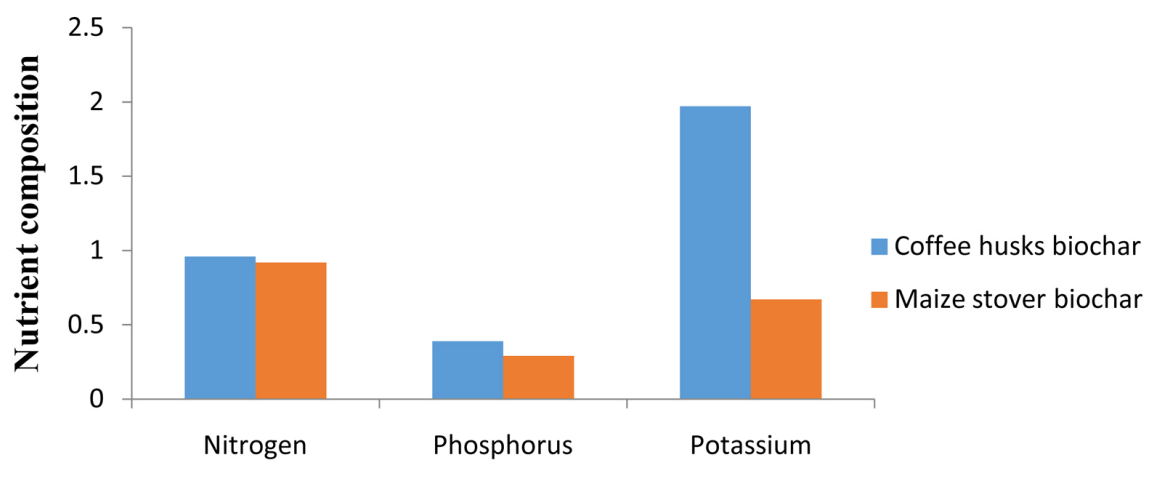

Elements

Figure 6. Comparison of the elemental nutrient content of coffee husks biochar and maize stover biochar.

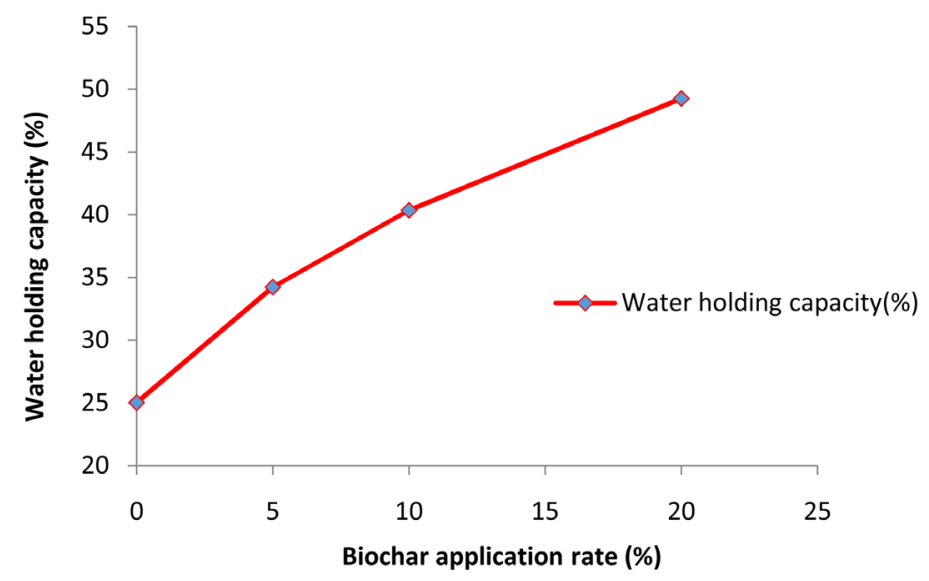

Figure 7. Water holding capacity of the soil with varying biochar application rate.

$20 \%$ showed a percentage increase in the water holding capacity by $11 \%, 21 \%$ and $19 \%$ respectively). This is comparable to the $18 \%$ increase in the water holding capacity by addition of $45 \%$ biochar by volume to sandy soils reported by [24].

Water holding capacities of biochar amended soils were relatively constant throughout the entire period, whereas water holding capacity of the control decreased rapidly throughout the entire sampling period $(\mathrm{P}<0.05)$ (Figure 8). This was probably due to the increase in the soil bulk density, since water holding capacity decreases with bulk density and the bulk density of biochar amended soils is relatively constant with time [25].

Water scarcity is a global issue threatening the sustainability of agricultural food production [26]. The ability of biochar amendments to improve soil water-holding capacity could enhance the sustainability of commercial agriculture in arid regions which are adversely impacted by water stress conditions.

\section{Conclusion}

In this study, the biochar derived from the coffee husks greatly depended on 


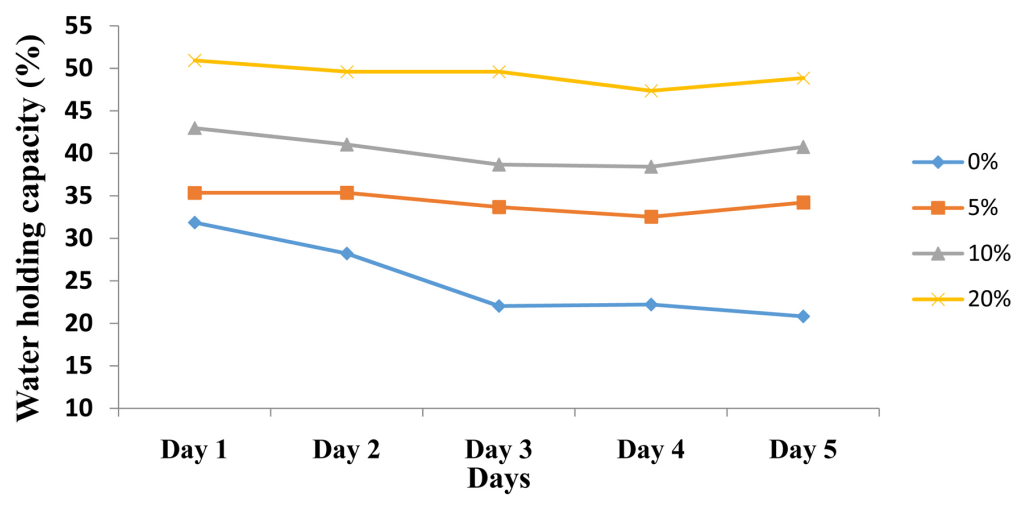

Figure 8. Water holding capacity of different treatments sampled on varying days.

pyrolysis conditions (Temperature and Residence time) with a maximum biochar yield of $36.87 \mathrm{wt} \%$ attained in the reactor, and the yield of biochar decreased as the temperature and residence time of pyrolysis in the reactor increased. Biochar was characterized by both proximate analysis and nutrient analysis. Proximate analysis included a relative fraction of fixed carbon, volatile matter and ash content and nutrient elemental analysis included proportions of elemental nutrients in terms of Nitrogen, Potassium and Phosphorus. The biochar produced from coffee husks contains high percentage of fixed carbon $(>60$ wt\%), suggesting that biochar from coffee husks is suitable for carbon sequestration and also contributes to high levels of soil organic matter. Biochar also contains nutrients with an inorganic (NPK) equivalent of (0.96:0.39:1.97) implying that coffee husks biochar is a good soil amendment. The research found that biochar used in this study increases water holding capacity of the soil by around $1.5 \%$ for each $1 \%$ added biochar. This becomes beneficial in areas of low water availability and also is another important attribute that prevents land degradation by erosion. Given the current state of knowledge, the coffee husks biochar has the potential for both greenhouse gas mitigation and as a soil amendment tool. Sustainable land management through biochar utilization may promote poverty reduction, as it results in increased soil fertility, and reduced need for fertilizer inputs which translate into more income.

\section{Conflicts of Interest}

The authors declare no conflicts of interest regarding the publication of this paper.

\section{References}

[1] Kiggundu, N., Ddungu, S.P., Wanyama, J., Cherotich, S., Mpairwe, D., Zziwa, E., Mutebi, F. and Falcucci, A. (2019) Greenhouse Gas Emissions from Uganda's Cattle Corridor Farming Systems. Agricultural Systems, 176, Article ID: 102649. https://doi.org/10.1016/j.agsy.2019.102649

[2] Lehmann, J., Gaunt, J. and Rondon, M. (2006) Bio-Char Sequestration in Terrestrial Ecosystems-A Review. Mitigation Adaptation Strategies for Global Change, 11, 
403-427. https://doi.org/10.1007/s11027-005-9006-5

[3] Sohi, S.P., Krull, E., Lopez-Capel, E. and Bol, R. (2010) A Review of Biochar and Its Use and Function in Soil. In: Advances in Agronomy, Elsevier, New York, 47-82. https://doi.org/10.1016/S0065-2113(10)05002-9

[4] Henao, J. and Baanante, C. (2006) Agricultural Production and Soil Nutrient Mining in Africa: Implications for Resource Conservation and Policy Development.

[5] UBOS (2013) Statistical Abstract. Uganda Bureau of Statistics, Kampala, Uganda.

[6] Komakech, A.J., Zurbrügg, C., Semakula, D., Kiggundu, N. and Vinnerås, B. (2015) Evaluation of the Performance of Different Organic Fertilizers on Maize Yield: A Case Study of Kampala, Uganda. Journal of Agricultural Science, 7, 28-37. https://doi.org/10.5539/jas.v7n11p28

[7] Okoboi, G. and Barungi, M. (2012) Constraints to Fertilizer Use in Uganda: Insights from Uganda Census of Agriculture 2008/9. Journal of Sustainable Development, 5, 99-113. https://doi.org/10.5539/jsd.v5n10p99

[8] Hunt, A.J., Sin, E.H., Marriott, R. and Clark, J.H. (2010) Generation, Capture, and Utilization of Industrial Carbon Dioxide. Chemistry Sustainability Energy Materials, 3, 306-322. https://doi.org/10.1002/cssc.200900169

[9] UCDA (2014) Uganda Cofee Development Authority. Annual Report. 23.

[10] Ndhlovu, M., Kiggundu, N., Wanyama, J. and Banadda, N. (2017) Effects of Incorporating Biochar into the Soil Using Power Tiller and Ox-Plough. Sustainable Agriculture Research, 6, 93-103. https://doi.org/10.5539/sar.v6n4p93

[11] Jourabchi, S.A., Gan, S. and Ng, H.K. (2014) Pyrolysis of Jatropha Curcas Pressed Cake for Bio-Oil Production in a Fixed-Bed System. Energy Conversion Management, 78, 518-526. https://doi.org/10.1016/j.enconman.2013.11.005

[12] Kabenge, I., Omulo, G., Banadda, N., Seay, J., Zziwa, A. and Kiggundu, N. (2018) Characterization of Banana Peels Wastes as Potential Slow Pyrolysis Feedstock. Journal of Sustainable Development, 11, 14. https://doi.org/10.5539/jsd.v11n2p14

[13] Owusu, P.A., Banadda, N., Zziwa, A., Seay, J. and Kiggundu, N. (2018) Reverse Engineering of Plastic Waste into Useful Fuel Products. Journal of Analytical Applied Pyrolysis, 130, 285-293. https://doi.org/10.1016/j.jaap.2017.12.020

[14] Aboagye, D., Banadda, N., Kiggundu, N. and Kabenge, I. (2017) Assessment of Orange Peel Waste Availability in Ghana and Potential Bio-Oil Yield Using Fast Pyrolysis. Renewable and Sustainable Energy Reviews, 70, 814-821.

https://www.astm.org/Standards/E897.htm https://doi.org/10.1016/j.rser.2016.11.262

[15] Omulo, G., Willett, S., Seay, J., Banadda, N., Kabenge, I., Zziwa, A. and Kiggundu, N. (2017) Characterization of Slow Pyrolysis Wood Vinegar and Tar from Banana Wastes Biomass as Potential Organic Pesticides. Journal of Sustainable Development, 10, 81-92. https://doi.org/10.5539/jsd.v10n3p81

[16] ASTM (2004) Standard Test Method for Volatile Matter in the Analysis Sample of Refuse-Derived Fuel.

[17] Okalebo, J., Gathua, K. and Woomer, P. (2002) Laboratory Methods of Soil and Plant Analysis. A Working Manual, 2, 29-68.

[18] Peng, X., Ye, L., Wang, C., Zhou, H. and Sun, B. (2011) Temperature-and Duration-Dependent Rice Straw-Derived Biochar: Characteristics and Its Effects on Soil Properties of an Ultisol in Southern China. Soil Tillage Research, 112, 159-166. https://doi.org/10.1016/j.still.2011.01.002

[19] Nguyen, T., Hilliard, M. and Rochelle, G.T. (2010) Amine Volatility in $\mathrm{CO}_{2}$ Cap- 
ture. International Journal of Greenhouse Gas Control, 4, 707-715.

https://doi.org/10.1016/j.ijggc.2010.06.003

[20] Joseph, S., Camps-Arbestain, M., Lin, Y., Munroe, P., Chia, C., Hook, J., Van Zwieten, L., Kimber, S., Cowie, A. and Singh, B. (2010) An Investigation into the Reactions of Biochar in Soil. Soil Research, 48, 501-515.

https://doi.org/10.1071/SR10009

[21] Mullen, C.A., Boateng, A.A., Goldberg, N.M., Lima, I.M., Laird, D.A. and Hicks, K.B. (2010) Bio-Oil and Bio-Char Production from Corn Cobs and Stover by Fast Pyrolysis. Biomass Bioenergy, 34, 67-74.

https://doi.org/10.1016/j.biombioe.2009.09.012

[22] Steiner, C., Das, K.C., Garcia, M., Förster, B., Zech, W. (2008) Charcoal and Smoke Extract Stimulate the Soil Microbial Community in a Highly Weathered Xanthic Ferralsol. Pedobiologia, 51, 359-366. https://doi.org/10.1016/j.pedobi.2007.08.002

[23] Shenbagavalli, S. and Mahimairaja, S. (2012) Production and Characterization of Biochar from Different Biological Wastes. International Journal of Plant, Animal Environmental Sciences, 2, 197-201.

[24] Tryon, E.H. (1948) Effect of Charcoal on Certain Physical, Chemical, and Biological Properties of Forest Soils. Ecological Monographs, 18, 81-115. https://doi.org/10.2307/1948629

[25] Basso, A.S., Miguez, F.E., Laird, D.A., Horton, R. and Westgate, M. (2013) Assessing Potential of Biochar for Increasing Water-Holding Capacity of Sandy Soils. $G C B$ Bioenergy, 5, 132-143. https://doi.org/10.1111/gcbb.12026

[26] FAO (2010) The State of Food Insecurity in the World: Addressing Food Insecurity in Protracted Crises. Food and Agriculture Organization of the United Nations (FAO), Rome. 